\title{
A Magyar Királyi Pénzügyőrség I. világháborús hősi halottjai és emlékük ápolása
}

(WWI Heroic Dead of the Royal Hungarian Finance Guard and Memorials to their Memory)

\section{Absztrakt}

Az I. világháború során, a Magyar Királyi Pénzügyőrség határszéli szakaszainál szolgáló személyi állomány a kezdetektől részt vett a harcokban. Helyismeretük miatt előszeretettel vették igénybe őket a határmenti harccselekmények során. A pénzügyőrök részt vettek hadifoglyok bekísérésében, objektumok és vonatszerelvények őrzésében is. 1926-ban a Mátyás utca 16. szám alatti pénzügyőr laktanyában márvány emléktáblát állítottak a háború során katonai vagy pénzügyőri szolgálatteljesítés közben életüket vesztett, név szerint ismert 236 fö pénzügyőrnek. A Pénzügyőrségi Szaklap 1926. XI. 1-jei száma „Az emléktábla leleplezése" címmel részletes tudósítást tett közzé az eseményről. A Pénzügyőr- és Adózástörténeti Múzeum gyüjteménye őrzi ezt a korabeli lapot a testületi szaksajtó sok más példányával együtt. Ezekből a lapokból az is kiderül, hogy a testület nem hagyta magukra a hadiözvegyeket és hadiárvákat, anyagi támogatással gondoskodott róluk.

$$
\begin{gathered}
\text { Kulcsszavak } \\
\text { Magyar Királyi Pénzügyőrség ; hősi halottak ; Pénzügyőrségi Szaklap ; pénzügyőr hősi halott emléktábla ; } \\
\text { Magyar Királyi Vámőrség }
\end{gathered}
$$

Abstract

From the beginning, personnel of the Royal Hungarian Finance Guard (RHFG) serving along the border fought in WWI. Because of their familiarity with the border area, they were relied upon during battles on the borderland. They were also used to chaperone POWs and watch over objects and trains. In 1926, a marble memorial plaque was unveiled in the finance guard barracks located on 16 Mátyás Street to the 236 finance guards who had lost their lives in WWI. The November 1st, 1926 issue of Pénzügyörségi Szaklap provided a detailed report of the "Unveiling of the Memorial Plague". The Customs and Tax History Museum has the issue in its collection, along with many other related journal issues. From these we have also learned that the RHFG did not abandon the widows and orphans whose husbands and fathers fell in the war; the organization provided financial support to them.

\section{Key words:}

Royal Hungarian Finance Guard ； heroic dead ； Pénzügyőrségi Szaklap ;

plaque commemorating the heroic dead of the Royal Hungarian Finance Guard ； Royal Hungarian Customs Guard 
A

z Osztrák-Magyar Monarchia trónörökösét és feleségét 1914. VI. 28-án ${ }^{1}$ Szarajevóban a szerb egység eszméjét megtestesíto „Egység vagy Halál” elnevezésű titkos szervezet ${ }^{2}$ terrorista tagja meggyilkolta Egy hónappal később 1914. VII. 28-án az Osztrák-Magyar Monarchia hadat üzent Szerbiának. A szövetségi szerződések értelmében egész Európa hadba lépett a század eleje óta jelen lévő hatalmi törekvésekből fakadóan. ${ }^{3}$

Kitört az I. világháború, amely jelentősen befolyásolta a pénzügyőrök életét is. Az ugyanis már 1914 előtt is nyilvánvaló volt, hogy a pénzügyőrök - mint a magyar állam polgári fegyveres örtestülete — személyi állományának a tagjai, nem mentesülhettek a háborús feladatok terhei alól. A kivételes hatalomról szóló 1912. évi törvény alapján a magyar rendvédelemi szervezetekben megélénkült a felkészülés a háborús teendőkre. ${ }^{4} 1914$ júliusában mozgósításra került sor, melynek során több pénzügyör is harcoló alakulat állományába került.

A Magyar Királyi Pénzügyőrség alapfeladata ugyan a háború kezdetén ugyanaz volt, mint az 1867es megalapításakor azaz a pénzügyi ellenőrzések lefolytatása a jövedékek és egyedáruságok területén, valamint a csempészet megakadályozása. A háborús viszonyok miatt azonban ezen feladatkörökbe tartozó tevékenységek jelentősen kibővültek. A Magyar Királyi Pénzügyőrség mindenkori szolgálati feladatainak teljesítési helyzetéről viszonylag hủ képet adnak a korabeli pénzügyőr újságok. ${ }^{5}$

A háború előestéjén a pénzügyőrség létszáma ${ }^{6}$ mintegy 5000 főtt tett ki. A pénzügyőrök közül a sorkötelesek, a tartalékosok és az önkéntesek teljesítettek hadiszolgálatot. Ám az 1914 júliusi mozgósítás során több olyan pénzügyőr is a haderő állományába került, akikre a törvények mentességet állapítottak meg. (I.sz. melléklet) Ezt az ellentmondást egy rendelet oldotta fel, így a már bevonult pénzügyőrök egy része a harci alakulatoktól visszakerült belterületi szolgálatra. A testület tagjai közül sokan egy éves önkéntes szolgálatra jelentkeztek. A pénzügyőrség személyi állományának a hadiszolgálatot teljesítő tagjait a hadvezetés általában összetett feladatokkal bízta meg, különösen a vámhatárok menti pénzügyőr szakaszok pénzügyőreit, hiszen kiváló helyismerettel rendelkeztek. ${ }^{7}$

A vámhatárokon szolgálatot teljesítő pénzügyőr szakaszok (II.sz. melléklet) müködése kiemelt fontosságú volt, mivel e szakaszok a személyi állománya külső határok (vámhatárok) hadmúveleti területté nyilvánításától népfölkelönek minősült, így katonai irányítás alá került és részt vett a határmenti harcokban. A határszéli szakaszok személyi állományát ellátták csukaszürke egyenruhával és tábori felszereléssel is. ${ }^{8}$

A pénzügyőröket tehát igénybe vették a határmenti harcok eredményes megvalósítása érdekében. Felderítő tevékenységükkel a katonai hírszerzésnek is kiváló szolgálatot tettek. A hadmüveleti területeken általában a pénzügyőrökre bízták a hadifoglyok bekísérését, objektumok és vonatszerelvények őrzését is. (III.sz. melléklet)

\section{A hős pénzügyőrök}

A I. világháború idején is rendszeresen - kéthetente - megjelenö Pénzügyigazgatás címü szakközlöny9 folyamatosan beszámolt a harctéri eseményekről, föként azokról a harci cselekményekről, amelyeknek a megvalósításában valamilyen formában a pénzügyőrök is részt vettek. A kortársak által legjelentösebbnek ítélt hősi cselekedeteket végrehajtó pénzügyőrök nevét emléktábla formájában is megörökítették.

Az Est címü napilap 1914. VIII. 14-én megjelent száma is tudósított az első fegyveres összecsapásról, amely során a Magyar Királyi Honvédség száz emberét 1914. VII. 30-án este egy honvéd főhadnagy vezetésével a Nándorfehérvárral (Belgrád) szemben levő borcsai ${ }^{10}$ határmenti pénzügyőr laktanyához vezényelték ki, feltehetően annak érdekében, hogy megakadályozza a szerb csapatok átkelését. A föhadnagy és száz honvédje a pénzügyőrség „János” nevü gőzösén ${ }^{11}$ (IV. sz. melléklet) este nyolckor indult el világítás nélkül Pancsováról és szorosan a magyar part mellett haladva éjjel 11 órakor érte el rendeltetési helyét. Másnap délután három vontatógőzös haladt fel a Dunán, egy őrnaszád kíséretében a szerb part mentén. Amikor az első hajó a nándorfehérvári vár és a magyar őrség közé került, a szerb partról, erős puskatüzelés kezdődött, de nem okozott kárt a magyar csapatban, mely viszonozta a tüzet. A szerbek ágyúlövéssel feleltek és mikor a három hajónak a tüzelő őrnaszád fedezete mellett sikerült a zimonyi révbe jutni, a honvédek ellen irányította ágyúit és mintegy hat kartács robbant fel körülbelül ötven lépésre a magyar rajvonal mögött. Sebesülés nem történt. ${ }^{12}$

Az I. világháború valószínủleg első pénzügyőr halottja DEÁK Barabás pénzügyőr fővigyázó volt, aki 1914. IX. 11-én az orsovai vasútállomás csomagosztályán éppen jelentést tett a szolgálatban lévő vámtisztviselőnek, amikor egy szerb lövedék szilánkja a hátába fúródott. Ennek következtében 1914. IX. 16-án elhunyt, mely eseményről a Pénzügyigazgatás címoldalán számolt be. ${ }^{13}$ 
DEÁK Barabás 1913. I. 30-tól az orsova-szkellai pénzügyőri szakasznál teljesített szolgálatot. Szemlészi vizsgát 1914 májusában tett, majd 1914 június elsején Nagyszurdokra helyezték és ott értesült a mozgósításról. Elsők közt vonult be a Császári és Királyi Haditengerészethez Polába, ahol gyorstüzelö ágyúelőmester beosztásba helyezték. Mivel a pénzügyi hatóság intézkedett, hogy a bevonult tartalékos katonákat az ország vámhatárának szélére helyezzék, ezért a katonai hatóság szabadságolta 1914. VIII. 15-én, azonban csak 1914. IX. 7-én érkezett vissza Orsovára, mivel a csatahajó, amelyen szolgált a dalmát partok mellett teljesített szolgálatot és az ellenséges hajók miatt csak késve érkezett a polai kikötőbe. Az elhunytat 1914. IX. 17-én temették el, felesége és két fia gyászolta. ${ }^{14}$

A pénzügyőrök kivették a részüket az 1914. évben a Kárpátok hegyvonulatán keresztül betörö orosz csapatok visszaverésében is. ${ }^{15}$ A pénzügyőrök a hivatásszerü munkájukon kívül - hasonlóan a csendőrökhöz - őrizték az utakat és a fontosabb mütárgyakat. A csendőrök és két pénzügyőr fővigyázó az ómoldovai Dunarészen három szerb hajót tartóztattak fel és foglaltak le. Ezzel a haditettel a szerbek dunai hajóparkjának egyharmada magyar kézre jutott. ${ }^{16} \mathrm{~A}$ hadsereg föparancsnoka különös elismerését fejezte ki a két pénzügyőrnek. ${ }^{17}$

Az elismerések sem maradtak el. ${ }^{18}$

JANKY Dénes pénzügyőri főbiztos a győrvámosi biztosi kerület vezetője, az 1. népfelkelö gyalogos ezred főhadnagya 1914. XI. 23-án a jabuncjei (Szerbia) ütközetben hősi halált halt. Családja, rokonai és a györi pénzügyigazgatóság személyi állománya gyászolta. ${ }^{19}$

Az orosz haderő csapatai 1914. XII. 1-én megszállták Bártfát, az oroszokkal való küzdelemben a bártfai pénzügyőri biztosi kerület személyzete is részt vett, amelyet mint külön pénzügyöri osztag az egyik népfelkelő zászlóaljhoz osztottak be. A csapat vezetője a bártfai pénzügyőri biztos volt. ${ }^{20}$ Ebben az ütközetben vesztette életét TAMÁs Béla pénzügyőr fövigyázó. ${ }^{21}$ TAMÁs Bélát a legfőbb hadvezetőség — az ellenség előtt tanúsított bátor magatartásáért — vitézségi éremmel tüntette ki és felkérte az eperjesi pénzügyigazgatóságot, hogy az érmet az elhunyt édesdapjának adja át. ${ }^{22}$

BUSZEK László a pénzügyőr tisztviselői kar tagja, besztercei előadó főbiztos, állami szolgálatának 23. évében halt hösi halált a harctéren. ${ }^{23}$

Kisjenői WOLF B. Béla pénzügyőr szemlész a 62. gyalogos ezred zászlósa, zászlóalj segédtiszt az északi harctéren srapnelltől találva halt hősi halált. ${ }^{24}$

A Magyar Királyi Pénzügyminisztérium a háború okozta károk - elsősorban a költségvetést ért elmaradások és többletkiadások terén - összeírását, azokról nyilvántartás készítését rendelte el és meghatározta az egységes nyilvántartás vezetésének szabályait is. A pénzügyőrséget érintően egyrészt a pénzügyőr szakaszokat ért károsodásokat, fegyverzet, konyhaberendezés és egyéb felszerelések esetében keletkezett károkat kellett számba venni.

A bevételi visszamaradások és/vagy többlet bevételek nyilvántartásának rendjét is, a jövedéki ágazat és a főbb jövedelmi ágakra nézve, így az egyenesadók, fogyasztási- és italadók, határvám, bélyeg, jogilletékek, díjak szerinti csoportosításban számba kellett venni. A visszamaradást, vagy bevételt a korábbi év tárgyhavával összevetve állapították meg.

ZSOLNAI András pénzügyőr fővigyázót, az Orosz-Lengyelországban harcoló 2. hadsereg „távolraíró" osztagának tagját az uralkodó ezüst vitézségi éremmel tüntette ki. A kitüntetést egy az északi harctéren váratlanul elrendelt visszavonulásban tanúsított hősiességének köszönhette. Társaival összegyüjtötte a jármüveket, távolraíró készülékeket és felszerelést, továbbá felszedték a kábelt. ${ }^{25}$

A pénzügyőröket - akik ,tartós alkalmazásban” álltak - mentesítették a népfölkelői tényleges szolgálat alól. A tartós alkalmazás alatt, azokat kellett érteni, akiket szabályosan felvettek folyó év (1915) január 1-jéig és esküt tettek.

„Hadbavonult pénzügyőrök” címmel 2015 márciusában közölt képes tudósítást a Tolnai Világlap

„A magyar pénzügyőrök is részt vesznek határaink védelmében és sokszor kitüntették már magukat hösiességükkel. Dicsöség árad e hösök tettei révén az egész pénzügyőri karra, mely mindvégig híven teljesitette hazája iránt való hazafias kötelességét. A határszéli pénzügyőrök most éppen úgy fel vannak fegyverezve, mint a rendes katonaság, s nem egyszer bizza meg öket a hadvezetöség nehéz feladatokkal, amelyeket azután derekasan és bátran oldanak meg. Többen kaptak már vitézségi kitüntetést a hadiszolgálatra rendelt pénzügyörök közül és bizonyára sokan fognak kapni még ezután is. "26

1915. VII. 20-án elhunyt az északi harctéren - a Bug folyó közelében, Dobrodwar mellett - EXNER László a Pénzügyigazgatás címủ szakközlöny kiadója. Édesapja a lapot 21 évvel korábban éppen az ö születésének évében vette át. ${ }^{27} \mathrm{~A}$ hazáért áldozta életét, ezért 1918. III. 25-én nagy ezüst vitézségi éremmel tüntették ki. ${ }^{28}$ DEÁK Barnabás nekrológját még ő írta a Pénzügyigazgatás szakközlönyben. EXNER Kornél a Pénzügyigazgatás címú szakközlöny föszerkesztöje nem csak a fiát, hanem édesapját EXNER 
Nándort is elveszítette a háborús években. A közigazgatási bíróság nyugalmazott ítélőbírája, életének 83. évében, Pozsonyban halt meg. ${ }^{29}$

1915. IX. 25-én elhunyt CSICS István pénzügyör fővigyázó, aki 13 hónapon át harcolt a szerb majd az olasz fronton, mint a 66. gyalogos ezred örvezetője. Az egyik laibachi tartalékkórházban tifusz következtében halt meg. Édesapja pénzügyi számtanácsosként az ungvári pénzügyi számvevőség fönöke volt, aki egyetlen fiát gyászolta. ${ }^{30}$

1915 októberében az osztrák-magyar, német és bolgár erők együttesen megszállták Szerbiát. A szerb pénzügyigazgatás közös irányításában később a magyar pénzügyőrök is részt vettek.

1916. VIII. 27-én Románia hadat üzent az Osztrák-Magyar Monarchiának és még aznap éjjel megtámadta Erdélyt, ${ }^{31}$ ahol az első csapatokat a határszéli pénzügyőrök és csendörök próbálták feltartóztatni, a román hadsereg első áldozatai éppen a szolgálatukat teljesítő pénzügyőrök voltak.

A román betörés veszteségeiről tudósított a Pénzügyörségi Szaklap. Megtudható belőle, hogy kik sebesültek meg, kik estek román fogságba, kik tüntek el. Valamint azt a szomorú tényt, hogy a brassói pénzügyigazgatóság hatósági területén az oláh betörés következtében és azt követő harcokban hösi halált haltak BABOS Károly és SzAKÁCS Rezső pénzügyör fővigyázók. ${ }^{32}$ A predeáli pénzügyőr szakasz 1917. I. 30-án megkezdte az újbóli müködését. ${ }^{33}$

A Magyar Királyi Pénzügyminisztérium elismerve a pénzügyőrök sikeres szolgálatellátását és tekintettel a nehézzé vált megélhetésre és ruházkodásra a háború folyamán a Magyar Királyi Pénzügyörség személyi állományának a tagjait különféle kedvezményekben és anyagi támogatásban részesítette. A tisztviselők és altisztek ${ }^{34}$ a háború első felében a harctereken állták meg a helyüket, a személyi állomány egy másik jelentős része pedig a határőrizetben és határvédelemben teljesítette példamutatóan szolgálati feladatait, de nem különben volt fontos az állami bevételek szempontjából a hátországban a pénzügyi ellenőrző szolgálat ellátása, valamint a terménykészletek rekvirálása sem. A pénzügyőrség tagjainak nyújtott kedvezmények voltak az élelmezési pótlék, a háborús családi pótlék, a háborús segély, a beszerzési előleg, a ruházkodási segély, az olcsó egyenruha posztó és ingyenes bakancs, valamint a vámhatármenti területeken szolgálatot teljesítő pénzügyőrök esetében az ingyen katonai ruha és felszerelés, valamint a hadi illetmények folyósítása. ${ }^{35}$

\section{A hősök emlékének ápolása}

A forrásokat olvasva ismerős nevekkel találkozhatunk, akik a testületnél már a nagy háború alatt is szolgálatot tejesítettek. Például: BAHUNEK Bélával, aki az önképzőkör létrehozásában játszott jelentős szerepet, BITTERMANN Bélával, aki később megalapította a Magyar Királyi Pénzügyőrségi Múzeumot, (V.sz. melléklet) vagy éppen KERÉKFFY Gilberttel, aki a későbbi hévízi gyógyház építésnek egyik kezdeményezöje volt.

A mozgósítások során BITTERMANN Béla császári és királyi fơhadnagyot is tényleges katonai szolgálatra rendelték be. ${ }^{36}$ A Pénzügyörségi Szaklap 1915-ben arról írt, hogy föbiztossá nevezték ki. ${ }^{37}$ A Budapesti Hirlap arról számolt be az „Adakozás” címü rovatában, hogy BITTERMANN Béla — akinek tartózkodási helye Újvidék volt — több helyre adakozott. ${ }^{38} \mathrm{~A}$ világháború alatt szolgálaton kívüli századossá léptették elő, ${ }^{39}$ elnyerte az uralkodó bizalmát, kitüntették a „Signum Laudis” bronz fokozatával, ${ }^{40}$ Állomáshelye ekkor a 3. hadsereg parancsnoksága volt.

BITTERMAN Bélát 1916 áprilisában, 21 hónapi szolgálat után mentették fel a katonai szolgálat alól, ezt követően újra átvette az erzsébetfalvai biztosi kerület vezetését. ${ }^{41}$

Nem sokáig lehetett Erzsébetfalván, hiszen 1916 júniusában a megszállt szerb területek pénzügyi közigazgatási teendőinek ellátása céljából a pénzügyminisztérium Szerbiába rendelte. ${ }^{42} \mathrm{~A}$ világháború után 1918-ban az Erzsébetfalván lévő biztosi kerülethez került vissza, itt kezdte újra a szolgálatot, vette át főbiztosként a kerület vezetését. Az 1926-os Szolnoki és Szolnokmegyei Alamanachban megyei föparancsnokként szerepelt. ${ }^{43}$

1926-ban visszakerült Budapestre, a Budapest Székesfővárosi Pénzügyigazgatóság, pénzügyőr elöadója és parancsnoka lett, I. osztályú pénzügyőr felügyelőként. ${ }^{44}$

A háború elvesztése, a forradalmak időszaka és a trianoni sokk megrázkódtatásként érte az országot. A testület tagjai a nehéz idők és a Magyar Királyi Pénzügyőrség újjászervezése után sem feledkeztek meg a nagy háborúban hösi halált halt társaikról.

1926. X. 17-én a Mátyás-utcai pénzügyőr laktanyában (építésének befejezése 1906) avatták fel a világháborúban hősi halált halt 236 pénzügyőrnek emléket állító emléktáblát. ${ }^{45}$ Az ünnepség kezdetekor, azaz 11 órakor a laktanya elé vonult a Magyar Királyi Pénzügyőrség díszszázada. ${ }^{46}$ Az ünnepségen megjelentek az állami vezetés képviselői, valamint a testület szakmai vezetésének kiválóságai, továbbá az önkormányzat képviselői és a római katolikus egyház, illetve a református egyház küldöttjei, akik 
kegyelettel emlékeztek meg az elesettekről. A személyi állomány nevében egy főbiztosi rangban lévő pénzügyőr mondott beszédet. Az emléktáblát a főváros polgármestere és a laktanya parancsnoka közösen vette át. ${ }^{47}$ (VI. + VII. + VIII.sz. melléklet)

A Pénzügyőrségi Szaklap 1927 júliusi számában tette közzé felhívását BITTERMANN Béla felügyelő, egy állandó Pénzügyőr Múzeum alapítására, ${ }^{48}$ amely szerint a múzeum alapításának célja, hogy összegyüjtsön a pénzügyőrséggel és szolgálatával kapcsolatos minden tárgyat, amelyet a pénzügyőrség használt, vagy amelyeket a pénzügyőrség kijátszására használtak pl. csempészet céljából.

1928. II. 27-én a Magyar Királyi Pénzügyminisztériumnak írt levelében kérte a pénzügyőrségi múzeum létrehozásának engedélyezését, amelyben célként jelölte meg a testületi múlt ápolását, történetének bemutatását, valamint, hogy a kiállított tárgyak, eszközök, a pénzügyőri altisztek számára oktatási célokat is szolgálhatnának. ${ }^{49}$

A főfelügyelő mindehhez anyagi támogatást nem kért, csak a fiumei pénzügyőri laktanya harmadik emeleten lévő tanterem biztosítását, ezért az engedélyt megadták. ${ }^{50}$

1930. X. 4-én BiTTERMANN Béla álma valóra vált, hiszen Budapesten a Fiumei út 6. szám alatt lévő pénzügyőr laktanyában megnyílt a Magyar Királyi Pénzügyőrségi Múzeum.

Az eseményről több újság is beszámolt. A Pesti Hirlap „A Pénzügyőrségi Múzeum felavatása” címmel, fényképes tudósítást jelentetett meg ${ }^{51}$ és természetesen a Pénzügyörségi Szaklap 1930. X. 15én megjelent száma is cikket közölt az eseményröl..$^{52}$ A cikk részletesen beszámolt az eseményröl és bemutatta a megjelenteket. ${ }^{53}$ (IX.sz. melléklet)

A pénzügyőrség 75 éves jubileumi ünnepsorozata részeként sajtótájékoztatót tartottak a Fiumei úti épületben. A Nemzeti Újság is tudósított az eseményről, beszámolt a múzeumban látottakról. ${ }^{54}$

Összességében megállapítható, hogy az I. világháború idején — részlegesen és időszakosan, a hadiállapottól függően - katonai felügyelet alá kerültek a Magyar Királyság külső határai, azaz a magyarromán és a magyar-szerb határok, amelyek egyben az Osztrák-Magyar Monarchia Magyarországra eső vámhatárait is alkották. E határszakaszokon határőrizeti szolgálatot ellátó magyar rendvédelmi testületek alakulatai pedig — a kivételes hatalomról szóló törvény alapján — az Osztrák-Magyar Monarchia hadereje területileg illetékes parancsnokságai alárendeltségébe kerültek, mivel a határmenti térséget hadmüveletei területté nyilvánították. ${ }^{55}$

E rendszer keretében kerültek át a pénzügyi tárca kompetenciájából a haderő alárendeltségébe a Magyar Királyi Pénzügyőrség vámhatár menti szakaszainak a személyi állománya népfelkelői státuszban, akik - a pénzügyőri alapfeladataik mellett — békeidőszakban is ellátták a vámhatárvonalak őrzését a Magyar Királyi Csendőrség határszéli őrseivel közösen. ${ }^{\mathbf{5 6}}$

A Magyar Királyságban a háború során a kivételes hatalomról szóló 1912. évi törvényben foglaltak szerint a rendvédelmi testületek nem a véderő főparancsnoksága alá kerültek, hanem a polgári kormány irányítása alatt maradtak a hadmüveleti területek kivételével. ${ }^{57}$ A rendvédelmi testületek személyi állománya azonban jelentős mértékben csökkent részben a behívások, föként azonban az önkéntes katonai szolgálatra jelentkezések nyomán. Egyben pedig megszünt e testületek személyi állományának az utánpótlása. A haderő ugyan igyekezett biztosítani a tartalékos állományból - döntően a frontszolgálatra alkalmatlan — katonákat a rendvédelmi testületek számára, ez a személyi állomány azonban a rendvédelmi feladatok ellátása tekintetében képzetlen volt. Ugyanekkor valamennyi rendvédelmi testület esetében gyarapodtak a rend fenntartásával kapcsolatos teendők. A létszámproblémák nyomán valamennyi rendvédelmi testület — ennek részeként a Magyar Királyi Pénzügyőrség is — nehéz helyzetbe került. ${ }^{58}$

A háborús szükségletekről való gondoskodás, többféle hadikölcsön, hitelműveletek sora, valamint a hadisegély-ügyek intézése jelentős mértékben igénybe vették a pénzügyi közigazgatás minden szervezeti egységét. Az I. világháború hadszíntereire kikerült pénzügyőrök miatt megfogyatkozott a szolgálati helyeken a munkaerö, egyre több és több feladat hárult egyes személyekre, nemkülönben a határszéli vámhivatalok szolgálatára. A világháború eseményei alatt a katonai szolgálatban álló pénzügyőrök közül 236 fớ $^{59}$ vesztette életét, a harctereken tanúsított hösies helytállásért számos pénzügyör kapott különböző kitüntetést.

Az I. világháborút a Magyar Királyság gazdasági katasztrófája és az állami-társadalmi összeomlás, az ország megcsonkítása, valamint az idegen megszállás követte. Az öszirózsás forradalom Magyar Népköztársasága után a magyarországi tanácsköztársaság idején a Magyar Királyi Pénzügyőrség lefegyverzésre került. A harminc éven aluli pénzügyöröket beosztották a Vörös Örség állományába, negyven éven felüli tagjait pedig minden ellenszolgáltatás nélkül elbocsátották a testület kötelékéből. A fegyvertelenné vált testület tagjai a Vörös Örségben ugyanolyan feladatokat láttak el, mint amilyet a korábbi szolgálati helyeiken. A pénzügyőrök közül csak azok kaptak fegyvert, akik a Vörös Hadsereg tagjaival részt vettek a határörizetben. A magyarországi tanácsköztársaság megdöntésével az új hatalmi rendszer 
visszaállította a Magyar Királyság közigazgatását. A „béketárgyalások” befejezéséig a Magyar Királyság ideiglenes határainak őrizetét és biztosítását a nemzeti hadsereg, a Magyar Királyi Állami Rendőrség, a Magyar Királyi Határrendőrség maradványai és a Magyar Királyi Csendőrség kijelölt alakulatai végezték.

A trianoni békediktátum szerint a történelmi Magyarország határai megszüntek, a magyar állam területe kétharmaddal csökkent, lakosságának pedig mintegy a fele idegen uralom alá került. ${ }^{60} \mathrm{Az}$ új vámterület szempontjából kiemelkedő jelentősége volt az 1924. évi vámtörvénynek. ${ }^{61}$ A gazdaság helyreállítása, az államháztartás egyensúlyának helyreállítása érdekében takarékossági és racionalizálási intézkedéseket foganatosítottak. Ehhez szükségessé vált a közszolgáltatások rendszerének teljes megreformálása, s mindezek mellett új bevételi forrásokról is gondoskodni kellett (pl. forgalmi adó, vagyonváltság).

A békediktátum nyomán újjászerveződő magyar államban a pénzügyőrség reorganizálására is sor került, melynek során az eredeti feladatrendszeréből fakadó teendőit alakították át az új körülményeknek megfelelöen. ${ }^{62}$

A Magyar Királyi Pénzügyminisztérium látszólag egy önálló katonailag szervezett fegyveres örtestülettel ${ }^{63}$, a Magyar Királyi Vámőrséggel is gyarapodott. ${ }^{64}$ Ennek a szervezetnek azonban nem voltak valódi vámfeladatai, hiszen a vámeljárásokat továbbra is a vámhivatalok végezték. A Magyar Királyi Vámőrség nyílt feladatát a határőrizeti teendők alkották. A testületnek azonban volt egy rejtett feladata is, nevezetsen a magyar állam határait érő támadás első csapásainak a felfogása, az ellenséges előrenyomulás ütemének a lassítása. Ebből a célból a nyílt feladatai végrehajtása érdekében létrehozott nyílt szervezetnek a rejtésében katonai alakulatokat müködtettek. Így jöhetett létre az a helyzet, hogy a Magyar Királyi Honvédség minden harmadik ezrede — rejtett alakulatként — a Magyar Királyi Vámőrség fedésében müködött. Ebböl a helyzetböl fakadóan pedig a vámőrség rejtetten a Magyar Királyi Honvédség katonai felügyelete alatt állt. ${ }^{\mathbf{6}}$

A két világháború közötti megváltozott körülményekhez kellett igazítani a Magyar Királyi Pénzügyőrség szolgálatellátását is. Ebből fakadóan pedig elengedhetetlen volt a pénzügyőrségi szakképzés megreformálása is. ${ }^{66}$

A polgári magyar állam időszakában a magyar rendvédelem integráns részeként müködött a Magyar Királyi Pénzügyőrség a határokon szorosan együttmüködve a magyar határőrizeti szervekkel, illetve háború idején a magyar haderő csapataival. ${ }^{67}$

1945 után — a magyarországi pártállam kiépítésének a részeként — a pénzügyőrség és a határőrizet szervezete is átalakításra került, ám a határok menti rendvédelmi feladatok ellátásában továbbra is együttmüködtek a magyar határőrség rendőrségbe történő integrálásáig. ${ }^{68}$ 


\section{Jegyzetek:}

${ }^{1}$ Az Osztrák-Magyar Monarchia haderejének 1914-es nyári hadgyakorlatát Bosznia-Hercegovinában rendezték meg, ide érkezett a trónörökös 1914. VI. 25-én. A hadgyakorlatot követően 1914. VI. 28-án feleségével Szarajevóba utazott hivatalos teendői miatt. Szerencsétlen volt ez a dátum választás, hiszen 1914. VI. 28. az 1389-es Szerbia töröktől elszenvedett vereségének évfordulója volt. Az elnyomó szerepét ebben az időszakban a szerb soviniszták számára a HABSBURGok jelentették.

KEEGAN: 76.p.

${ }^{2}$ GALÁNTAI: 83-85.p.

${ }^{3}$ Loc.cit. 44.p.

4 1912/LXIII.tc. ; PARÁDI József: A magyar rendvédelem története. 99.p.

${ }^{5}$ DEÁK: A polgári magyar állam rendvédelmi sajtója 1867-1944. 80.p. ; PARÁDI József: A dualizmuskori magyar pénzügyörség és vámhivatalok.

${ }^{6}$ PARÁDI József: A Magyar Királyi Pénzügyminisztérium határőrizeti feladatai az Osztrák-Magyar Monarchia magyarországi vámhatárain 1867-1914. 185.p.

${ }^{7}$ PARÁDI Ákos: A Magyar Királyi Pénzügyőrség teendői a katonai határőrizetre való áttérés időszakában. 50.p.

${ }^{8}$ SZAKÁCS: 1.p.

${ }^{9}$ Pénzügyigazgatás a pénzügyminisztérium, a pénzügyigazgatóságok, a pénzügyi számvevőségek, az állampénztárak, a kir. adóhivatalok, a pénzügyőrség, a kir. sóhivatalok és a kir. vámhivatalok szakközlönye.

${ }^{10}$ Borcsa egykor önálló község a Duna partján, ma Nándorfehérvár (szerb nevén Belgrád) külvárosa Szerbiában.

${ }^{11}$ A János gőzőst 1913. V. 27-én vette át a hajóra kinevezett pénzügyőrségi személyzet BöHM Dezső felügyelő vezetésével a DGT ( Duna -Gőzhajózási Társaság) Óbudai Hajógyárban. Innen indultak le az aldunai szolgálatra Pancsovára. Az I. világháború után is a pénzügyőrség tulajdonában maradt ismeretlen ideig.

Az aldunai gőzhajó.

${ }^{12}$ Hol volt tüzben az első honvéd.

${ }^{13}$ A kötelességteljesítés halottja. 289-291.p.

${ }^{14}$ Loc.cit. 291.p.

15 1914. X. 2-án a beregszászi pénzügyigazgatóság azt a parancsot kapta, hogy négy pénzügyőrt hadiszolgálatra rendeljen ki. MAGDINECZ János volóci szakaszvezető szemlész, PoPOviTs Mirón, Zsigmond Lajos és KonDOR Bertalan pénzügyőri vigyázó ilyen módon került szolgálatba és felderítő csapatokat vezettek a katonaság előtt ismeretlen terepen.

Pénzügyőreink a háborúban.

16 a két pénzügyőr SzABó Pál és Orosz Dénes volt. A Sumadia személyszállító, 51 férfi szerb férfiutassal, a Beligrad személyszállító 150 szerb férfiutassal, a Krajna vontatógőzös 21 utassal és 11 uszállyal.

A magyar pénzügyőrség és a háború.

${ }^{17}$ A pénzügyőrség köréből. (1915)

${ }^{18}$ MAJOR János pénzügyőri fővigyázó a csornai pénzügyőri szakasztól, mint tartalékos tizedes vonult be, és az orosz harctéren tanúsított hősies, vitézi magatartásáért október hónapban szakaszvezetővé léptették elő, novemberben pedig a vitézségi ezüst érdemrenddel tüntették ki.

A magyar pénzügyőrség a háborúban. (1914)

${ }^{19}$ Halálozások. (1914)

${ }^{20}$ A pénzügyőr osztag vezetője Mies Károly bártfai pénzügyőr biztos volt. SZAKÁCS: op.cit.

${ }^{21}$ A magyar pénzügyőrség a háborúban. (1915)

${ }^{22}$ Kitüntetett pénzügyörök.

${ }^{23}$ A magyar pénzügyőrség a háborúban. (1915) op.cit.

${ }^{24}$ Loc.cit.

${ }^{25}$ Loc.cit.

${ }^{26}$ Hadbavonult pénzügyőrök.

${ }^{27}$ A mi gyászunk.

${ }^{28}$ Kitüntetés a hősi halál után.

${ }^{29}$ EXNER Kornél (Beregszász, 1867. VII. 3. - Bp., 1938. XI. 16.) Jogász hazai és külföldi jogi tanulmányok után 1891-ben pénzügyminisztériumi szolgálatba lépett. 1889-től a budapesti egyetem magántanára, 1913-tól néhány évig a közigazgatási bíróság bírája, majd újból a pénzügyminisztériumban teljesített szolgálatot, 1920-ban mint államtitkár nyugalomba vonult. 1895-től 1920-ig, a Pénzügyigazgatás címü lap szerkesztője volt. Főbb mủvei voltak: 1. Dolgozatok a pénzügyi jog köréből (Bp., 1904), 2. Az egyenes adók reformja (Bp., 1907), 3. Magyar pénzügyi jog (Bp., Adóügyi politikánk Bp., 1918), 4. Az új magyar adórendszer (Bp., 1920), 5. Az államháztartás egyensúlya (Bp., 1926). Szépirodalmi munkája: Színésznő és kritikus (vígjáték, Pozsony, 1890).

${ }^{30}$ Halálozások. (1915)

${ }^{31}$ GALÁNTAI: op.cit. 298.p.

32 A pénzügyőrség köréböl. (1917)

${ }^{33}$ Román betörés.

${ }^{34}$ MAGASVÁRI: 82-90.p.

35 KLESZKY: 222.p.

${ }^{36}$ A pénzügyőrség köréből. (1916/10-11)

${ }^{37}$ Főbiztosi kinevezések és áthelyezések.

38 BITTRERMANN Béla több helyre adakozott: a háborúban világtalanná lett hőseink részére, a háborúban lévő katonáink karácsonyára, a háborúban elesett hőseink özvegyei és árvái részére, a Szent Antal szegényeinek, a tüdővészes katonáknak. Adakozás.

${ }^{39}$ Az elöléptetés időpontja 1915. VII. 1.

Hivatalos rész. 
${ }^{40}$ Signum Laudis: I. Ferenc József (Schönbrunn, Bécs - 1830, augusztus 18. - Schönbrunn, Bécs - 1916. november 21.) Magyar Király (1867. VI. 8. - 1916. XI. 21. között) által 1890. III. 12-én alapított katonai érdemérem.

Bronz Katonai Érdemérem a katonai érdemkereszt szalagján, melynek felterjesztése 1915. december 27-én történt, adományozása: 1916. március.

${ }^{41}$ A pénzügyörség köréböl. (1916/10-11)

42 A pénzügyörség köréböl. (1916/12)

${ }^{43}$ SzABÓ Barna: Szolnoki és Szolnokmegyei Almanach 1926. 29.p.

${ }^{44}$ Áthelyezések és megbízatások.

${ }^{45}$ A müvészi emléktábla alkotója IsTóK János szobrászművész volt.

${ }^{46}$ A díszszázad parancsnoka RAUSCHMANN József tartalékos százados volt.

${ }^{47} \mathrm{Az}$ ünnepségen megjelent FÁBRY Dániel őrgy. szárnysegéd kíséretében József királyi herceg, a hadügyminisztérium nevében ovács BÉLA tábornok, a Magyar Királyi Honvédség föparancsnoksága képviseletében JÁNKY Kocsárd és KISS Ferenc tábornok, a kormányzó és a pénzügyminiszter közös képviselője, továbbá SIPőCZ Jenő a főváros polgármestere, a római katolikus egyház nevében dr. SZABÓ P. Piusz, a református egyház képviseletében pedig dr. GöDE Lajos. A testület személyi állománya nevében BARDÓCz János pénzügyör főbiztos mondott beszédet. A laktanya parancsnoka BITTERMANN Béla pénzügyőr felügyelö volt.

236 hősi halált halt pénzügyőr emléke. ; Az emléktábla leleplezése.

${ }^{48}$ Felhívás az összes tényleges és nyugdíjas pénzügyőri tisztviselőkhöz és altisztekhez.

49 A Pénzügyőrségi Múzeum örvendetes gyarapodása.

${ }^{50}$ NAV-PAM. Ad./51-2015. Múzeumalapítására és muzeális emlékek gyüjtésére vonatkozó iratok.

${ }^{51}$ A Pénzügyőrségi Múzeum felavatása.

${ }^{52}$ Megnyílt a pénzügyörségi múzeum.

${ }^{53}$ A rendezvényen megjelentek: dr. BALÁsy Antal államtitkárt, dr. JANKovich Antal miniszteri tanácsost a Pénzügyminisztériumból, dr. KERÉKFFY Gilbert, LAHNER Kálmán I. oszt. pénzügyőri felügyelö, a székesfővárosi pénzügyigazgatóság részéröl dr. SzABÓ László és FoRGó István miniszteri tanácsos pénzügyigazgató helyettesek.

${ }^{54}$ Hetvenötéves a magyar pénzügyörség. (Dicsőséges és derüs emlékek a pesti pénzügyőr múzeumban).

${ }^{55}$ PARÁDI József: Áttérés a háborús határőrizetre az első világháború előtt.

${ }^{56}$ Idem: A Magyar Királyi Csendőrség határőrizeti feladatai 1891-1914. ; Idem: A Magyar Királyi Pénzügyminisztérium határőrizeti feladatai az Osztrák-Magyar Monarchia magyarországi vámhatárain 1867-1914. op.cit.

57 1912/LXIII.tc. op.cit.

${ }^{58}$ PARÁDI József: A hátország rendvédelme 1914-1918. 108-124.p.

59 1926. X. 17.-én a Mátyás-utcai pénzügyőri laktanyában avatták fel IsTóK János szobrászművész által készített emléktáblát, amely a világháborúban hősi halált halt 236 pénzügyőrnek állított emléket.

${ }^{60}$ SUBA: 59-60.p.

${ }^{61}$ 1924/XXI.tc. ; ZSÁMBOKINÉ: 176-183p.

${ }^{62}$ SZABÓ: A pénzügyi igazgatás szervezeti keretei egykor és most a rendészeti feladatok tükrében.

${ }^{63}$ A , katonailag szervezett fegyveres örtestület” és a ,polgári fegyveres örtestület” a polgári magyar állam időszakában használt terminológia volt. A fegyveres testületek szolgálati szabályzatainak általában az elején szerepelt az a mondat, hogy a szervezet polgári fegyveres örtestület, vagy katonailag szervezett fegyveres örtestület.

A „,katonailag szervezett fegyveres örtestületek” személyi állományai körében a függelmi viszonyok katonaiak voltak. A testületi tagok katonai rendfokozati rendszer szerinti rangokat viseltek, személyükben katonának minősültek. Személyükben a honvédelmi tárca kompetenciájába tartoztak függetlenül attól, hogy a testületüket mely tárca irányította. A katonailag szervezett fegyveres őrtestületek személyi állományainak a tagjait a katonákra általában vonatkozó jogosultságok megillették, a kötelezettségek pedig terhelték.

Ezzel szemben a „polgári fegyveres örtestületek” személyi állományai körében a függelmi viszonyok hivatalnokiak voltak. A testületi tagok nem a katonai rendfokozati rendszer, hanem a testületek rendfokozati rendszerei szerinti rangokat viselték. A személyükben nem minősültek katonának, így nem a honvédelmi tárca, hanem a szervezetüket irányító minisztérium kompetenciájába tartoztak. A polgári fegyveres őrtestületek személyi állományainak a tagjait nem a katonákra, hanem a hivatalnokokra általában vonatkozó jogosultságok illették meg, illetve kötelezettségek terhelték. (a szerk.)

PARÁDI József: A katonailag szervezett őrtestület és a polgári örtestület.

${ }^{64} 6$ 200/1921. (VIII. 25.) ME.r.

${ }^{65}$ PARÁDI József: A magyar állam határőrizete 1920-1941. 73-76.p. ; Idem: A Magyar Királyi Vámőrség a polgári magyar állam rendvédelmi testülete. 81-91.p.

${ }^{66}$ SZABÓ: A magyar pénzügyőri képzés intézményi kereteinek fejlödése. 118.p.

${ }^{67}$ PARÁDI József: A magyar határörizet a kiegyezéstől a II. világháború kitöréséig 1867-1939.

${ }^{68}$ FóRIZS ; ZsIGOVITS: 109-123.p. 
Forrás-és irodalomjegyzék (a jegyzetekben alkalmazott röviditések oldása):

\section{MONOGRÁFIÁK KISMONOGRÁFIÁK ÉS HASONLÓ JELLEGÜ KÖTETEK}

GALÁNTAI
$(2 . ; 3 . ; 31 . ;)$

KEEGAN

$(1 . ;)$

PARÁDI József: A magyar rendvédelem története.

(4.;)

SUBA

(60.;)

\section{TANULMÁNYOK}

DEÁK: A polgári magyar állam rendvédelmi sajtója 1867-1944.

(5.;)

FÓRIZS

(68.;)

MAGASVÁRI

(34.,)

PARÁdi Ákos: A Magyar Királyi Pénzügyőrség teendői a katonai határőrizetre való áttérés időszakában.

(7.;)

PARÁDI József: A Magyar Királyi Csendőrség határőrizeti feladatai 1891-1914. (56.;)

PARÁDI József: A Magyar Királyi Pénzügyminisztérium határőrizeti feladatai az Osztrák-Magyar Monarchia magyarországi vámhatárain 1867-1914. (6.;56.;)

PARÁDI József: Áttérés a háborús határőrizetre az első világháború előtt. (55.;)

PARÁDI József: A dualizmuskori magyar pénzügyőrség és vámhivatalok. (5.;)

PARÁDI József: A Magyar Királyi Vámőrség a polgári magyar állam rendvédelmi testülete.

(65.;)

PARÁDI József: A hátország rendvédelme 1914-1918.

(58.;)
GALÁNTAI József: $A z$ I. világháború. Budapest, 2000², Korona Kiadó. 543 p. HU-ISBN 9789639191817.

- KeEgAn, John: Az első világháború. [The First World War.] Ford.: MoLNÁr György. Budapest, 2014, Akadémia Kiadó. 657 p. HU-ISBN 978963 059503 2. /Hadiakadémia./ HU-ISSN 2062-8498.

PARÁDI József et al. (szerk.): A magyar rendvédelem története. Budapest, 1996², Osiris. 367 p. HU-ISBN 9630479583.

- SuBA János: Magyarország államhatárának változásai 1867-1947 között. Budapest, 2003. Tipico Design Kft. 229 p. HU-ISBN 9637623299.

DEÁK József: A polgári magyar állam rendvédelmi sajtója 1867-1944. 6588.p. In PARÁDI Ákos (szerk.): Ünnepi tanulmányok Parádi József 65. születésnapja tiszteletére. Budapest, 2015, Szemere Bertalan Magyar Rendvédelem-történeti Tudományos Társaság. HU-ISBN 978963898289 6. /Salutem, 2./ HU-ISSN 2416-2078

- FóRIZs Sándor: A határőrség megszervezése és müködése 1945-1956. 555-607.p. In BoDA József — ISASZEGI János — PÓSÁN László — VESZPRÉMY László (szerk.): Őrzők vigyázzatok a határra! Határvédelem, határőrizet, határvadászok a középkortól napjainkig. Budapest, 2017, Zrínyi Kiadó. 910 p. HU-ISBN 9789633275603.

- MAGASVÁRI Adrienn: Kivonat a pénzügyőrség személyi állományának történetéből (1867-1919). 82-91.p. In ZsÁMBOKINÉ Ficskovszky Ágnes (szerk.): Válogatott tanulmányok a Vám-és Pénzügyöri Tanszék fennállásának 25. évfordulója alkalmából. Budapest, 2016, NKE Rendészettudományi Kar Vám- és Pénzügyőri Tanszék. 196 p. HU-ISBN 9786155057724.

PARÁDI Ákos: A Magyar Királyi Pénzügyőrség teendői a katonai határőrizetre való áttérés időszakában. Rendvédelem-történeti Füzetek (Acta Historiae Praesidii Ordinis), XXVII.évf. (2017) 54.sz. 45-59.p. HU-ISSN 1216-6774.

PARÁDI József: A Magyar Királyi Csendőrség határőrizeti feladatai 18911914. Hadtörténelmi Közlemények, CI.évf. (1988) 1.sz. 56-92.p. HU-ISSN 0017-6540.

PARÁDI József: A Magyar Királyi Pénzügyminisztérium határőrizeti feladatai az Osztrák-Magyar Monarchia magyarországi vámhatárain 18671914. Hadtörténelmi Közlemények, CIV.évf. (1989) 2.sz. 177-196.p. HUISSN 0017-6540.

PARÁDI József: Áttérés a háborús határőrizetre az első világháború előtt. Rendvédelemtörténeti Füzetek (Acta Historiae Praesidii Ordinis), IV.évf. (1994) 5.sz. 13-17.p. HU-ISSN 1216-6774. A tanulmány korábbi változata 1993. szeptember 21-én Budapesten hangzott el, a Szemere Bertalan Magyar Rendvédelem-történeti Tudományos Társaság által szervezett rendvédelem-történeti tudományos konferencia-sorozatnak a „Háború, forradalom, trianon” címü V. konferenciáján. A publikált tanulmány az előadás javított, bővített és átdolgozott változata.

PARÁDI József: A dualizmuskori magyar pénzügyőrség és vámhivatalok. Rendvédelem-történeti Füzetek (Acta Historiae Praesidii Ordinis), VIII.évf. (1998) 9.sz. 82-85.p. HU-ISSN 1216-6774. A tanulmány korábbi változata 1997. szeptember 23-án, Budapesten hangzott el a Szemere Bertalan Magyar Rendvédelem-történeti Tudományos Társaság által szervezett rendvédelem-történeti tudományos konferenciasorozatnak ,, Gazdasági rendvédelmünk a XIX-XX. században.” címü IX. konferenciáján. A publikált tanulmány az előadás javított, bővített és átdolgozott változata.

PARÁDI József: A Magyar Királyi Vámőrség a polgári magyar állam rendvédelmi testülete. Rendvédelem-történeti Füzetek (Acta Historiae Praesidii Ordini), XIV.évf. (2014) 39-40-41-42.sz. 81-98.p. HU-ISSN 1216-6774.

PARÁDI József: A hátország rendvédelme 1914-1918. 108-124.p. In SzIDIROPULOSZ Archimédesz (szerk.): Trianoni Szemle Évkönyv. VII. évfolyam. Budapest, 2015, Trianoni Kutatóintézet Közhasznú Alapítvány. 311 p. HU-ISSN 2060-2502. 
PARÁDI József: A katonailag szervezett örtestület és a polgári őrtestület.

(63.;)

PARÁDI József: A magyar határőrizet a kiegyezéstől a II. világháború kitöréséig 1867-1939.

(67.;)

SzABÓ: A magyar pénzügyőri képzés intézményi kereteinek fejlődése. (66.;)

SzABÓ: A pénzügyi igazgatás szervezeti keretei egykor és most a rendészeti feladatok tükrében.

(62.;)

ZsÁMBOKINÉ

(61.;)

ZSIGOVITS

(68.;)

\section{CIKKEK}

Adakozás.

(38.;)

Az aldunai gőzhajó.

(11.;)

Áthelyezések és megbízatások.

(44.;)

Az emléktábla leleplezése.

(47.;)

Felhívás az összes tényleges és nyugdíjas pénzügyőri tisztviselőkhöz és altisztekhez.

(48.;)

Főbiztosi kinevezések és áthelyezések. (37.;)

Hadbavonult pénzügyőrök.

(26.;)

Halálozások. (1914)

(19.;)

Halálozások. (1915)

(30.;)

Hetvenötéves a magyar pénzügyőrség. (Dicsőséges és derüs emlékek a pesti pénzügyör múzeumban).

(55.;)

Hivatalos rész.

(39.;)

Hol volt tüzben az első honvéd.

(12.;)

236 hősi halált halt pénzügyőr emléke. (47.;)

Kitüntetett pénzügyőrök.

(22.;)

Kitüntetés a hősi halál után.

(28.;)

KLESZKY

(35.;)
PARÁDI József: A katonailag szervezett őrtestület és a polgári őrtestület. Rendvédelem-történeti Füzetek (Acta Historiae Praesidii Ordinis), XXV.évf. (2015) 43-44-45-46.sz. 77-85.p. HU-ISSN 1216-6774.

PARÁDI József: A magyar határőrizet a kiegyezéstől a II. világháború kitöréséig 1867-1939. 481-510.p. In BoDA József — IsASZEGI János — PósÁN László - VESZPRÉMY László (szerk.): Örzök vigyázzatok a határra! Határvédelem, határörizet, határvadászok a középkortól napjainkig. Budapest, 2017, Zrínyi Kiadó. 910 p. HU-ISBN 9789633275603.

SzABÓ Andrea: A magyar pénzügyőri képzés intézményi kereteinek fejlödése. Rendvédelem-történeti Füzetek (Acta Historiae Praesidii Ordinis) XXV.évf. (2015) 43-44-45-46.sz. 117-126.p. HU-ISSN 1216-6774.

- SzABÓ Andrea: A pénzügyi igazgatás szervezeti keretei egykor és most a rendészeti feladatok tükrében. 351-356.p. In GAÁL Gyula - HAUTZINGER Zoltán (szerk.): Szent Lászlótól a modernkori magyar rendészettudományig. Pécs, 2017, Magyar Hadtudományi Társaság Határőr Szakosztályának Pécsi Szakcsoportja. 397 p. HU-ISBN — /Pécsi Határőr Tudományos közlemények, XIX./ HU-ISSN 1589-1674.

- ZsÁmbokiné Ficskovszky Ágnes: Az 1924-es Autonóm és Szerződéses Magyar Vámtarifa a korabeli hírek tükrében. 176-195.p. In ZsÁMBOKINÉ Ficskovszky Ágnes (szerk.): Válogatott tanulmányok a Vám-és Pénzügyőri Tanszék fennállásának 25. évfordulója alkalmából. Budapest, 2016, NKE Rendészettudományi Kar Vám- és Pénzügyőri Tanszék. 196 p. HU-ISBN 9786155057724 .

- ZSIGOVITS László: Vámosok és határőrök a határforgalom ellenőrzésében 1945-2007. Rendvédelem-történeti Füzetek (Acta Historiae Praesidii Ordinis), XXVI.évf. (2016) 51.sz. 109-137.p. HU-ISSN 1216-6774.

- Adakozás. (Szerkesztőségi közlemény) Budapesti Hirlap, XXXV.évf. (1915) 310.sz. 12.p.

- Az aldunai gőzhajó. (Szerkesztőségi közlemény) Pénzügyőrségi Szaklap, VI.évf. (1913) 11.sz. 172-173.p.

- Áthelyezések és megbízatások. (Szerkesztőségi közlemény) Pénzügyőrségi Szaklap, XVI.évf. (1926) 9.sz. 136.p.

- Az emléktábla leleplezése. (Szerkesztőségi közlemény) Pénzügyőrségi Szaklap, XVI.évf. (1926) 21.sz. 334-337.p.

Felhívás az összes tényleges és nyugdíjas pénzügyőri tisztviselőkhöz és altisztekhez. Pénzügyőrségi Szaklap, XVII.évf. (1927) 13-14.sz. 223.p.

Főbiztosi kinevezések és áthelyezések. (Szerkesztőségi közlemény) Pénzügyőrségi Szaklap, VIII.évf. (1915) 16-17.sz. 200.p.

- Hadbavonult pénzügyőrök. (Szerkesztőségi közlemény) Tolnai Világlapja, XV.évf. (1915) 11.sz. 14.p.

- Halálozások. (Szerkesztőségi közlemény) Pénzügyigazgatás, XXIV.évf. (1914) 24.sz. 381.p.

Halálozások. (Szerkesztőségi közlemény) Pénzügyigazgatás, XXV.évf. (1915) 21.sz. 336.p.

Hetvenötéves a magyar pénzügyőrség. (Dicsőséges és derüs emlékek a pesti pénzügyör múzeumban). (Szerkesztőségi közlemény) Nemzeti Újság, XXIV.évf. (1942) 225.sz. 11.p.

— $\quad$ Hivatalos rész. Budapesti Közlöny, XLIX.évf. (1915) 176.sz. 2.p.

- Hol volt tüzben az első honvéd. (Szerkesztőségi közlemény) Az Est, V.évf. (1914) 201.sz. 3.p.

236 hősi halált halt pénzügyőr emléke. (Szerkesztőségi közlemény) Pesti Napló, LXXVII.évf. (1926) 237.sz. 6.p.

— Kitüntetett pénzügyörök. (Szerkesztőségi közlemény) Pénzügyigazgatás, XXV.év. (1915) 10.sz. 162.p.

- Kitüntetés a hősi halál után. (Szerkesztőségi közlemény) Pénzügyigazgatás, XXVIII.évf. (1918) 11.sz. 137.p.

- KLESZKY Gyula: A pénzügyőrségnek a háborúban nyújtott kedvezmények. Pénzügyigazgatás, XXVII.évf. (2017) 16.sz. 222.p. 
A kötelességteljesítés halottja. (13.;14.;)

A magyar pénzügyőrség és a háború. (16.;)

A magyar pénzügyőrség a háborúban. (1914)

(18.;)

A magyar pénzügyőrség a háborúban. (1915)

(21.;23.;24.;25.;)

Megnyílt a pénzügyőrségi múzeum. (52.;)

A mi gyászunk.

(27.;)

Pénzügyőreink a háborúban.

(15.;)

A pénzügyőrség köréből. (1914)

(17.;)

A pénzügyőrség köréből. (1916/10-11) (36.;41.;)

A pénzügyőrség köréből. (1916/12) (42.;)

A pénzügyőrség köréből. (1917)

(32.;)

A Pénzügyőrségi Múzeum felavatása. (51.;)

A Pénzügyőrségi Múzeum örvendetes gyarapodása.

(49.;)

A román betörés.

SZAKÁCS

(8.;20;)

\section{ALMANACHOK}

SzABó Barna: Szolnoki és Szolnokmegyei Almanach 1926.

(43.;)

\section{KÉZIRATOK}

PARÁDI József: A magyar állam határörizete 1920-1941.

(65.;)

LEVÉL- IRAT- ÉS DOKUMENTUMTÁRI GYÜJTEMÉNYEK

NAV-PAM

(50.;)

\section{JOGSZABÁLYOK}

1912/LXIII.tc.

(4.;57.;)

1924/XXI.tc.

(61.;)

6 200/1921. (VIII. 25.) ME.r.

(64.;) (1915) 17.sz. 242. p. melléklet. 73-76.p.
- A kötelességteljesítés halottja. (Szerkesztőségi közlemény) Pénzügyigazgatás, XXIV.évf. (1914) 19.sz. 289-291.p.

- A magyar pénzügyőrség és a háború. (Szerkesztőségi közlemény) Pénzügyigazgatás, XXIV.évf. (1914) 17.sz. 268.p.

- A magyar pénzügyőrség a háborúban. (Szerkesztőségi közlemény) Pénzügyigazgatás, XXIV.évf. (1914) 24.sz. 382.p.

A magyar pénzügyőrség a háborúban. (Szerkesztőségi közlemény) Pénzügyigazgatás, XXV.évf. (1915) 1.sz. 12.p.

- Megnyílt a pénzügyőrségi múzeum. (Szerkesztőségi közlemény) Pénzügyörségi Szaklap, XX.évf. (1930) 20.sz. 9-10.p.

- A mi gyászunk. (Szerkesztőségi közlemény) Pénzügyigazgatás, XXV.évf.

- Pénzügyőreink a háborúban. (Szerkesztőségi közlemény) Pénzügyigazgatás, XXIV.év.(1914) 20.sz. 316-317.p.

- A pénzügyőrség köréből. (Szerkesztőségi közlemény) Pénzügyigazgatás, XXIV.évf. (1914) 23.sz. 364.p.

— A pénzügyőrség köréből. (Szerkesztőségi közlemény) Pénzügyigazgatás, XXVI.évf. (1916) 10-11.sz. 163-164.p.

- A pénzügyőrség köréböl. (Szerkesztőségi közlemény) Pénzügyigazgatás, XXVI.évf. (1916) 12.sz. 180.p.

- A pénzügyőrség köréből. (Szerkesztőségi közlemény) Pénzügyigazgatás, XXVII.évf. (1917) 5.sz. 76.p.

- A Pénzügyőrségi Múzeum felavatása. (Szerkesztőségi közlemény) Pesti Hírlap, LII.évf. (1930) 226.sz. 4.p.

A Pénzügyőrségi Múzeum örvendetes gyarapodása. (Szerkesztőségi közlemény) Pénzügyőrségi Szaklap, XXIII.évf. (1938) 11-13.sz. 4.p.

- A román betörés. (Szerkesztőségi közlemény) Pénzügyőrségi Szaklap, X.évf. (1917) 4.sz. 41.p.

- SzAKÁCs Tamás: A Magyar Királyi Pénzügyörség az I. világháborúban. A Mi lapunk, (A Pénzügyör melléklete) XIX.évf. (2016) 3.sz. 1-2.p.

- Szabó Barna (szerk.): Szolnoki és Szolnokmegyei Almanach 1926. Szolnok, 1926, Friedmann Sándor. 191 p.

PARÁDI József: A magyar állam határőrizete 1920-1941. Kandidátusi értekezés (MTA). Kézirat. Budapest, 1990. I.köt. 264 p. + II.köt. 265-567 p.

- NAV (Nemzeti Adó- és Vámhivatal) PAM (Pénzügyőr-és Adózástörténeti Múzeum) iratainak gyüjteménye

— 1912/LXIII.tc. a háború esetére szóló kivételes intézkedésekről.

— 1924/XXI.tc. a vámtarifáról.

- 6 200/1921. (VIII. 25.) ME.r. a vámőrség létesítéséről. Magyarországi Rendeletek Tára, LV.évf. (1922) I.füzet. 223-232.p. 


\section{Mellékletek jegyzéke:}

I. sz. melléklet

Hadiszolgálatba vonult pénzügyőr-csapat tábori felszereléssel. (1915)

II. sz. melléklet

Határszéli pénzügyőrök őrjárata az első világháború alatt

III. sz. melléklet

Határszéli lovas pénzügyőrök hírszerző szolgálatban (1916)

IV.sz. melléklet

A „János” nevű csavaros gőzhajó az óbudai hajógyári öböl bejáratánál, háttérben a Margitsziget, feltehetőleg az elkészülte után. (1901)

V. sz. melléklet

Bittermann Béla 1879-

VI. sz. melléklet

József főherceget a pénzügyőrök vasárnapi ünnepén Bittermann Béla felügyelő fogadja a Mátyás-utcai laktanya előtt

VII. sz. melléklet

József főherceg elvonul a pénzügyőrök sorfala előtt, mögötte Bittermann Béla pénzügyőri felügyelö, tőle balra Dr. Kerékffy Gilbert pénzügyőri felügyelö

VIII. sz. melléklet

Az ünnepség pillanatai a Mátyás-utcai laktanyában. A kép elején hosszú kabátban József főherceg, szemben középen Bittermann Béla pénzügyőri felügyelö, hátul Dr. Kerékffy Gilbert pénzügyőri felügyelő

IX. sz. melléklet

A Magyar Királyi Pénzügyőrségi Múzeum megnyitása (jobbról a negyedik Bittermann Béla pénzügyőri főfelügyelö) 1930. október 4.

Hadiszolgálatba vonult pénzügyőr-csapat tábori felszereléssel. (1915)

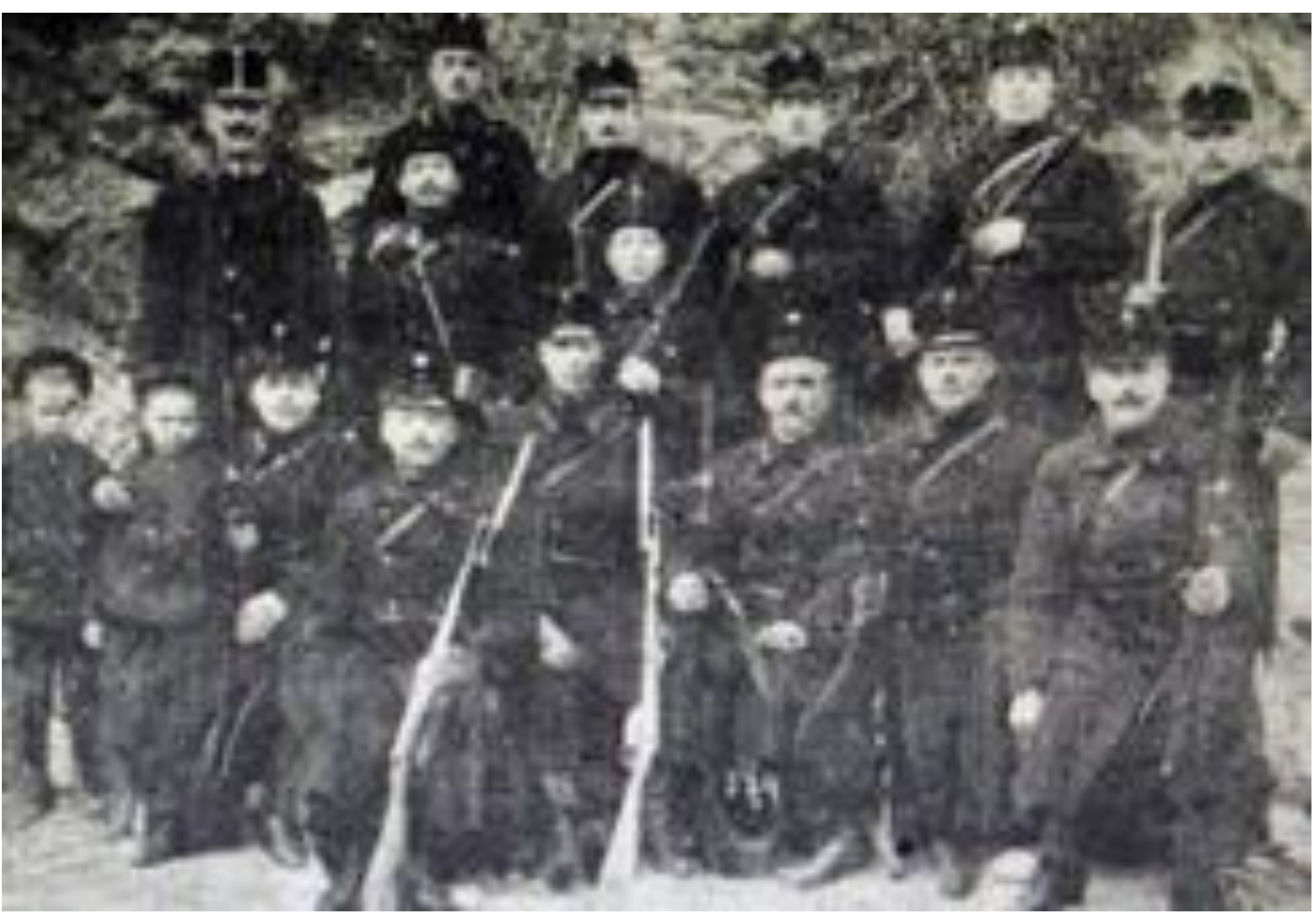

Forrás! Hadbavonult pénzügyőrök. Tolnai Világlapja 1915. évf. 11. szám 14. p. 


\section{Határszéli pénzügyörök őjárata az elsö világháború alatt}

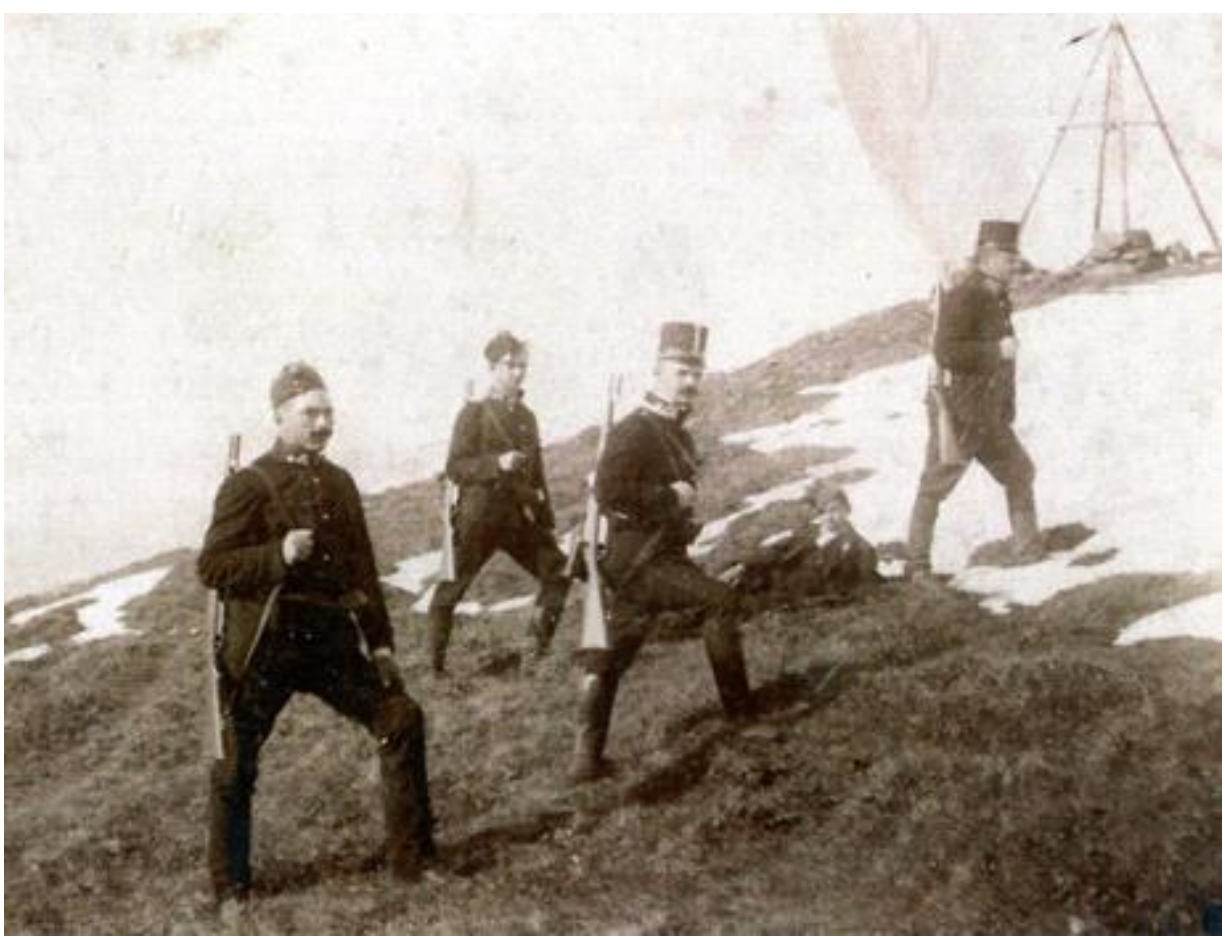

Forrás! A NAV KEKI Pénzügyőr- és Adózástörténeti Múzeum gyüjteményéből, Schodits Adolf felvétele

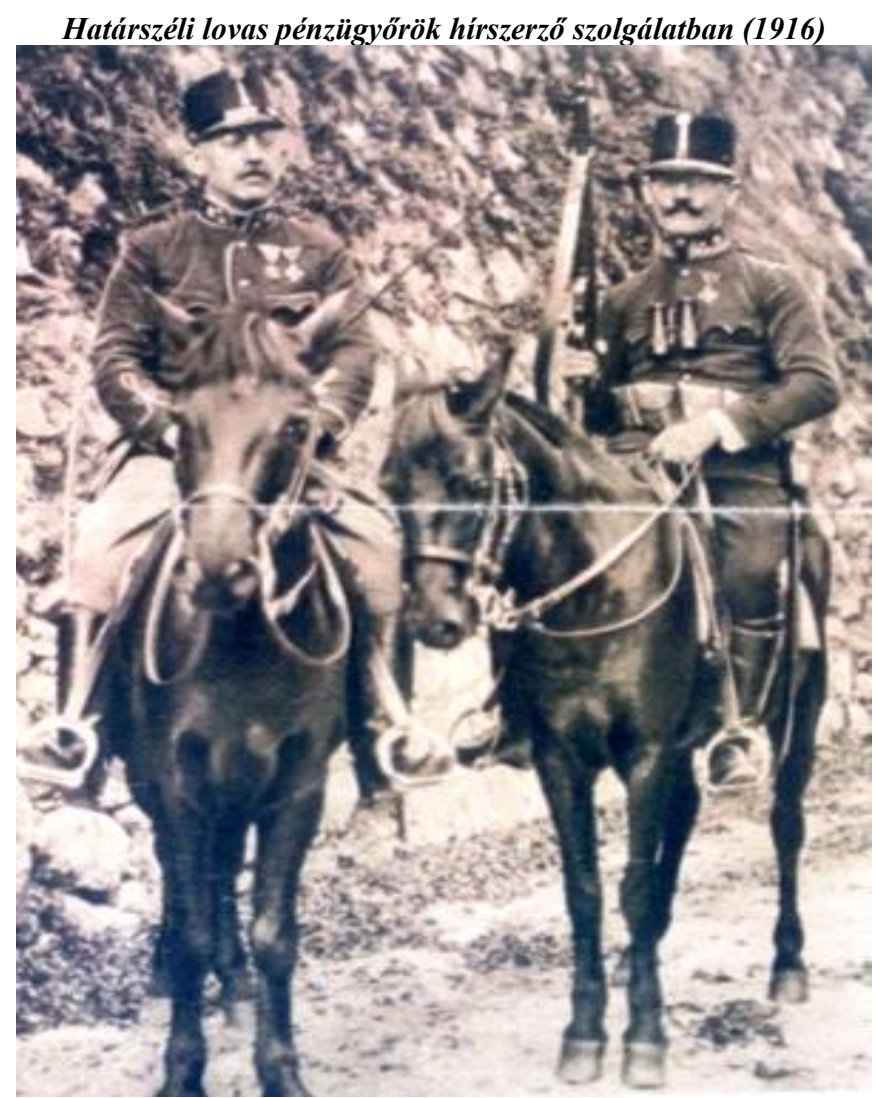

III. sz. melléklet

Forrás! A NAV KEKI Pénzügyőr- és Adózástörténeti Múzeum gyüjteményéből, Érdekes Újság 
IV.sz. melléklet

A „János” nevü csavaros gözhajó az óbudai hajógyári öböl bejáratánál, háttérben a Margitsziget, feltehetöleg az elkészülte után. (1901)

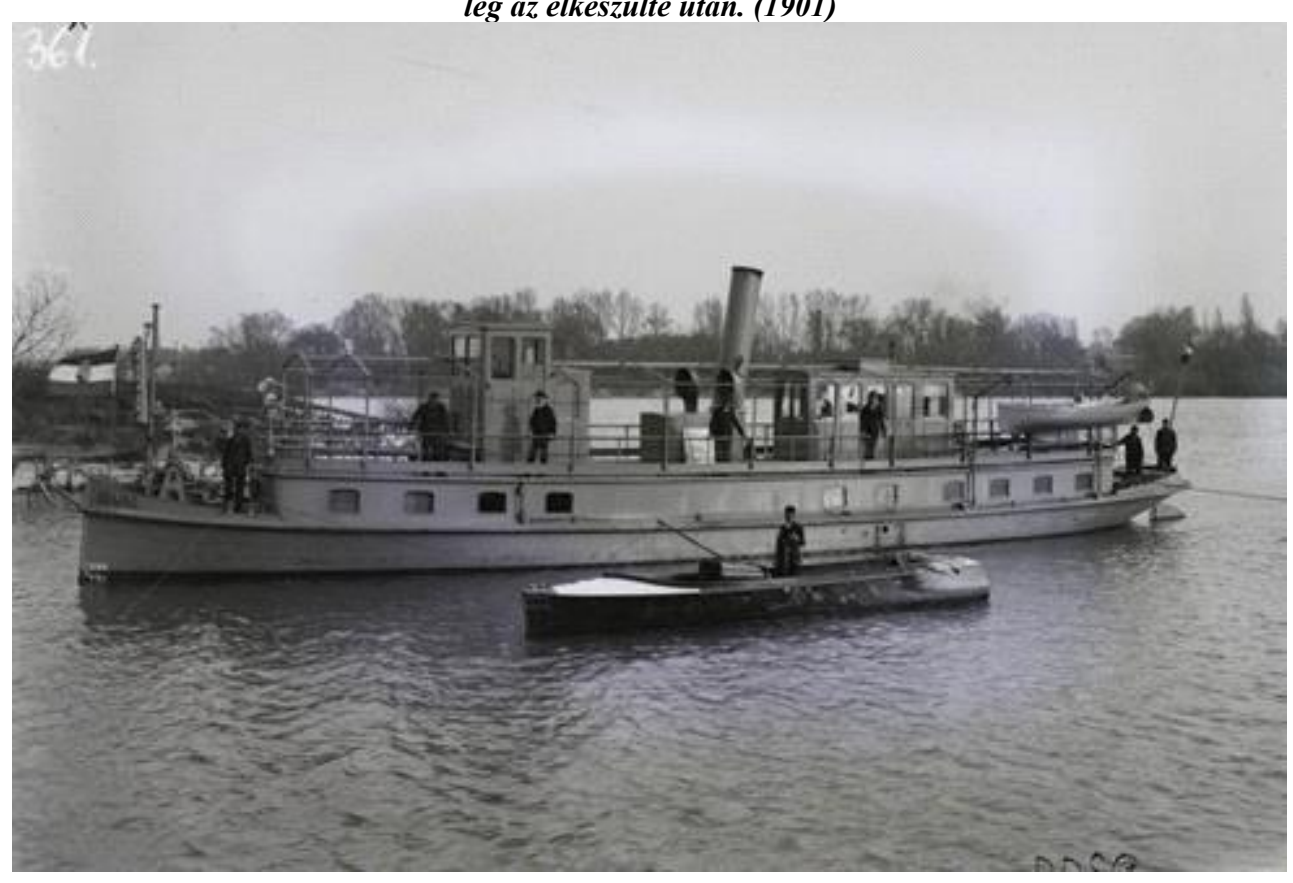

Forrás! Turi Zsolt: Bittermann Béla a Magyar Királyi Pénzügyörségi Múzeum alapitója. Megjelent születésének 140. évfordulójára. /kézirat/ 100. p.

Bittermann Béla 1879-

V. sz. melléklet
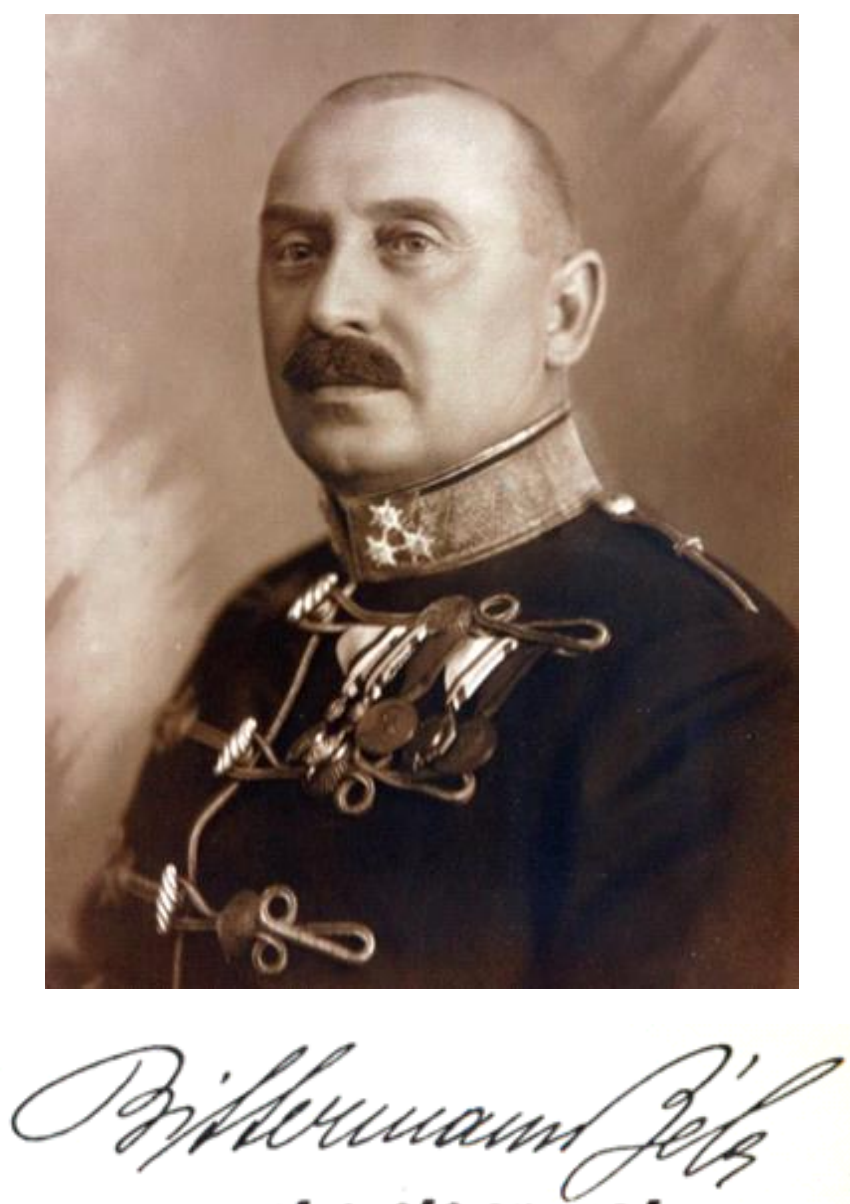

Forrás! A NAV KEKI Pénzügyör- és Ađözózäsörténeti Múzeum gyűjteményéből 
VI. sz. melléklet

József föherceget a pénzügyörök vasárnapi ünnepén Bittermann Béla felügyelö fogadja a Mátyás-utcai laktanya elött

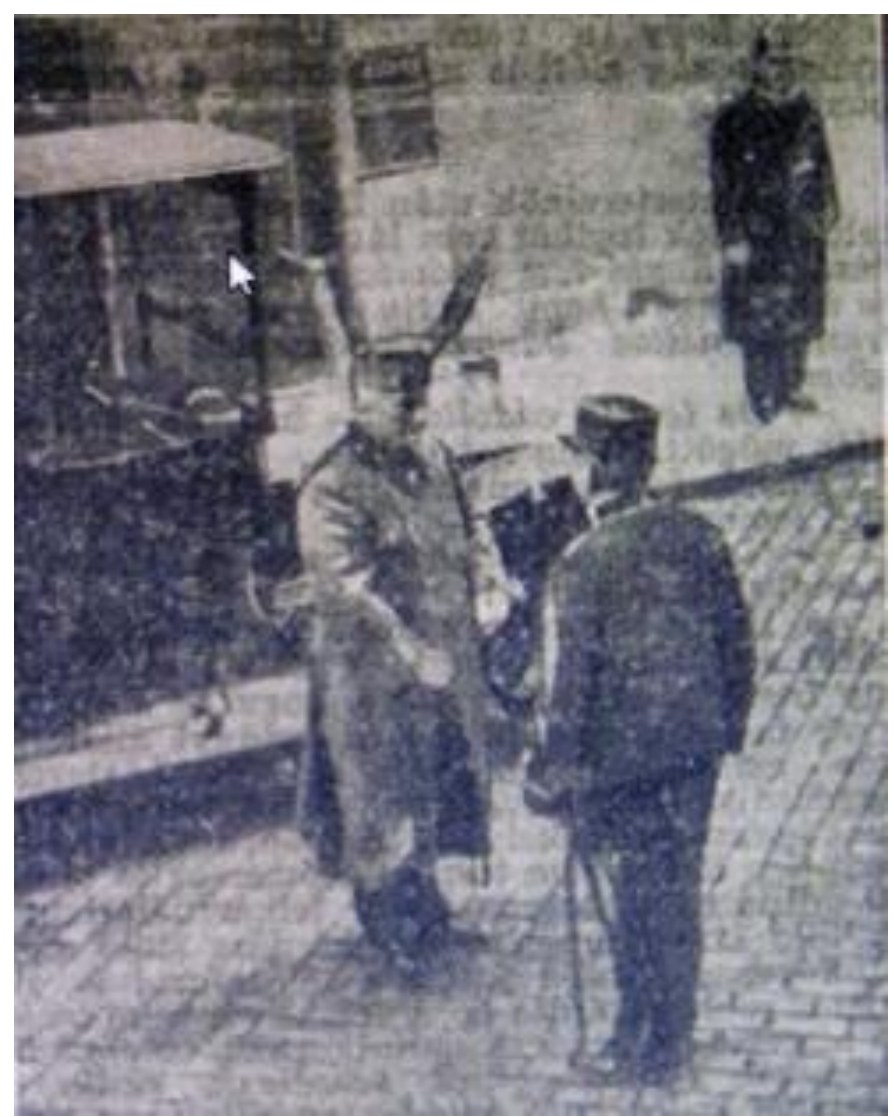

Forrás! Pesti Napló, 77. évf.(1926. október 19.) 237. sz., 6. p.

VII. sz. melléklet

József föherceg elvonul a pénzügyőrök sorfala elött, mögötte Bittermann Béla pénzügyőri felügyelö, tőle balra Dr. Kerékffy Gilbert pénzügyöri felügyelö

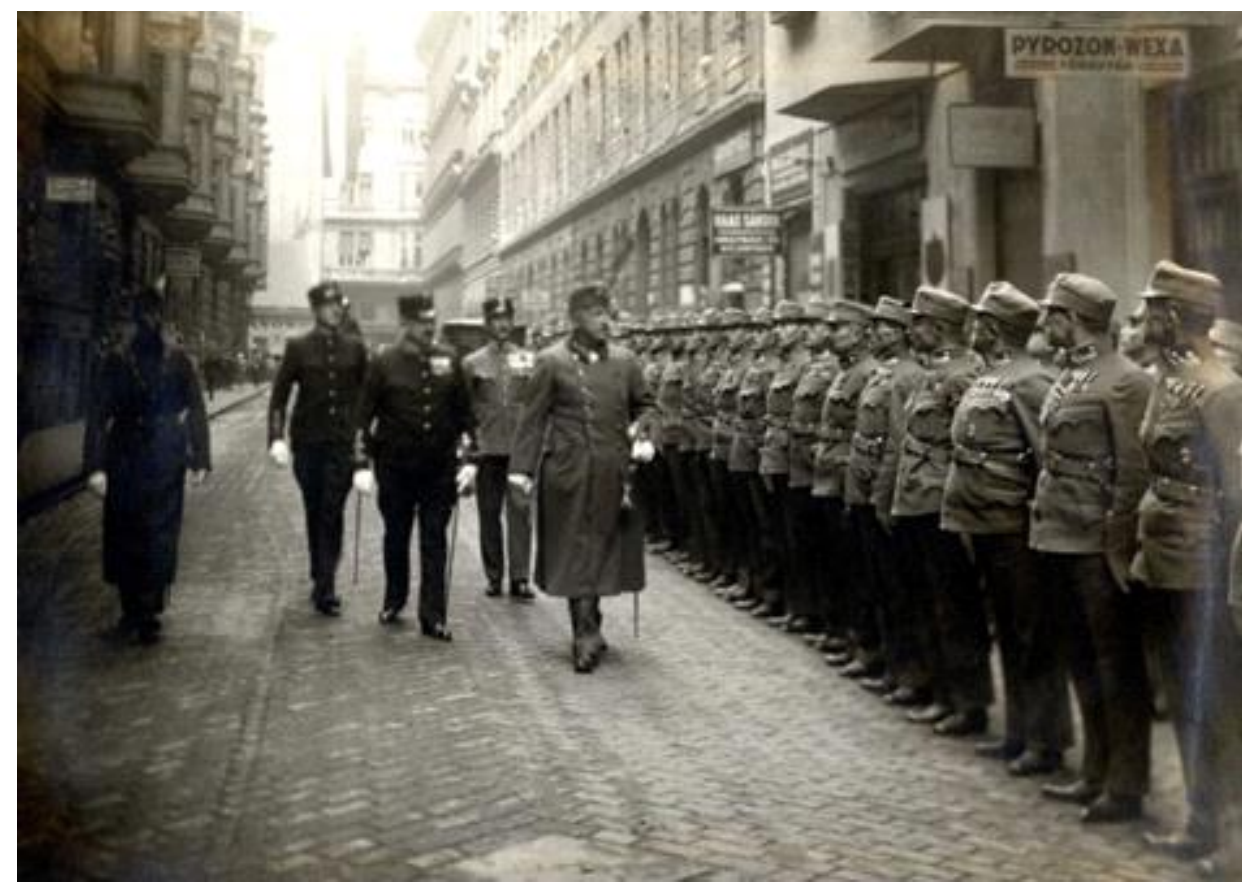

Forrás! A NAV KEKI Pénzügyőr- és Adózástörténeti Múzeum gyüjteményéből 
Az ünnepség pillanatai a Mátyás-utcai laktanyában. A kép elején hosszú kabátban József föherceg, szemben középen Bittermann Béla pénzügyöri felügyelö, hátul Dr. Kerékffy Gilbert pénzügyőri felügyelö

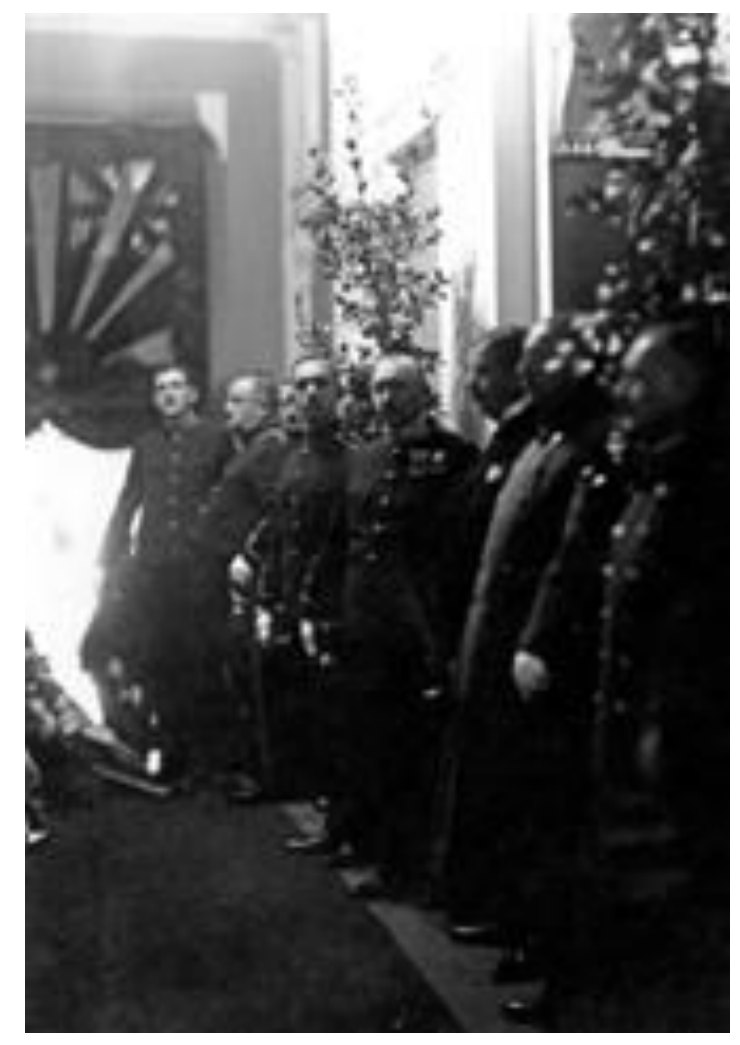

Forrás! A NAV KEKI Pénzügyör- és Adózástörténeti Múzeum gyűjteményéből

IX. sz. melléklet

A Magyar Királyi Pénzügyőrségi Múzeum megnyitása (jobbról a negyedik Bittermann Béla pénzügyőri föfelügyelö) 1930. október 4.

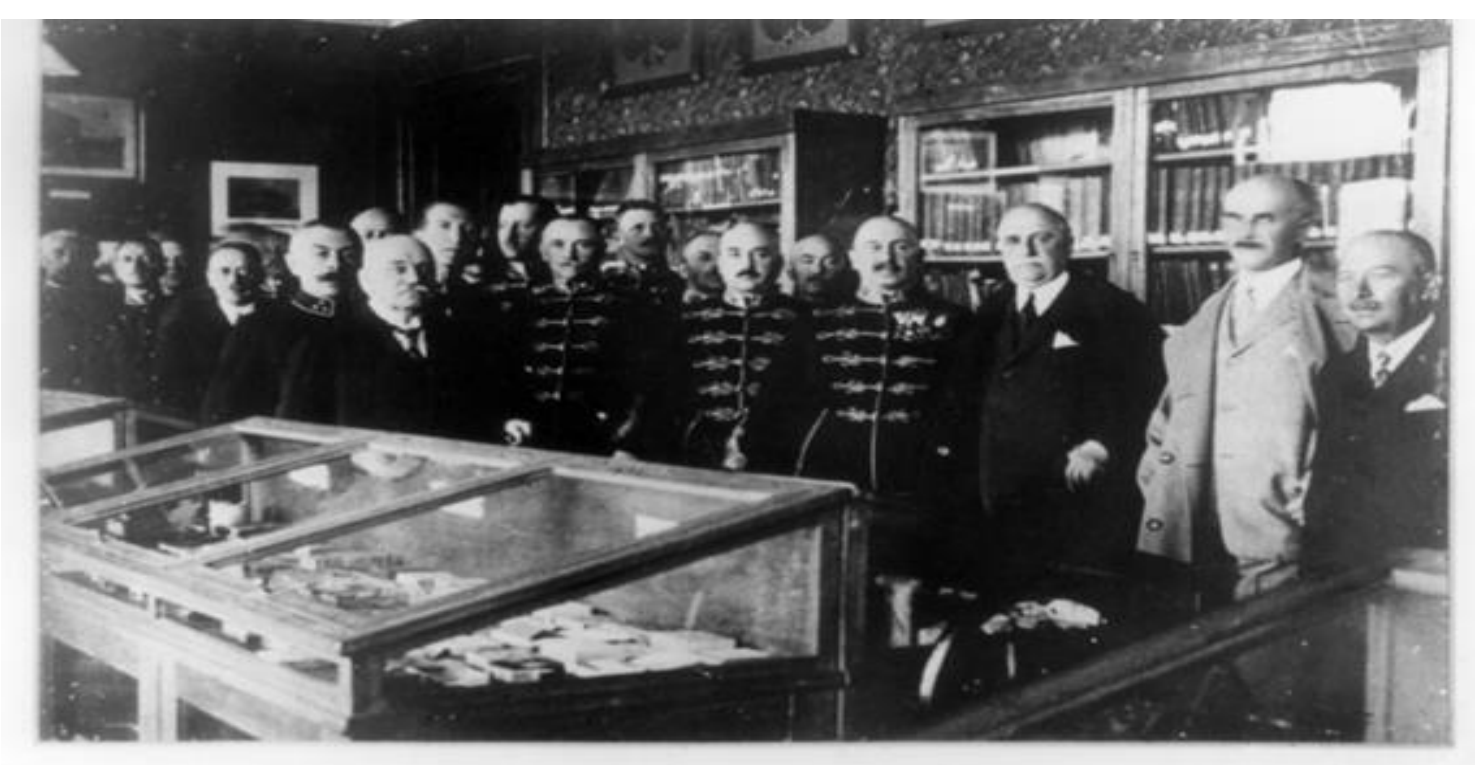

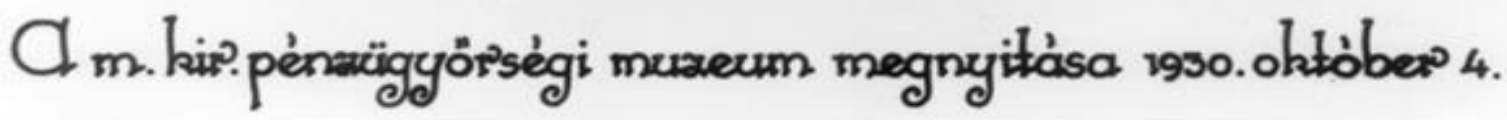

Forrás! ! A NAV KEKI Pénzügyőr- és Adózástörténeti Múzeum gyüjteményéből 